PublisherName : BioMed Central

PublisherLocation : London

PublisherlmprintName : BioMed Central

\title{
Articles selected from Faculty of 1000 in November 2003
}

\begin{tabular}{|lll|}
\hline & Articlel $n f o$ \\
ArticlelD & $: 999$ \\
ArticleDOI & $: 10.1186 /$ ar1031 & \\
ArticleCitationID & $:$ E3 \\
ArticleSequenceNumber & $: 14$ \\
ArticleCategory & $:$ Article selection & \\
ArticleFirstPage & $: 1$ \\
ArticleLastPage & $: 2$ \\
ArticleHistory & $:$ RegistrationDate $:$ 2003-11-20 \\
& & OnlineDate \\
ArticleCopyright & $:$ BioMed Central Ltd2003-11-20 \\
ArticleContext & $:$ 130755566 \\
\hline
\end{tabular}

I ain Mcl nnes, Aff1

Corresponding Affiliation: Aff1

Email: ibmi1w@clinmed.gla.ac.uk

Aff1 Centre for Rheumatic Diseases, Queen Elizabeth Building, Royal Infirmary, Glasgow G3I 2ER, UK

\section{Articles selected from Faculty of 1000}

\section{References}

1. Grakoui A, Shoukry NH, Woollard DJ, Han JH, Hanson HL, Ghrayeb J, Murthy KK, Rice CM, Walker CM: HCV persistence and immune evasion in the absence of memory T cell help. Science. 2003, 302: 659-62. For the Faculty of 1000 evaluation of this article please see: http://arthritisresearch.com/viewpoints/ar1031.asp\#grakoui 
2. Ubersax JA, Woodbury EL, Quang PN, Paraz M, Blethrow JD, Shah K, Shokat KM, Morgan DO: Targets of the cyclin-dependent kinase Cdk1. Nature. 2003, 425: 859-64. For the Faculty of 1000 evaluation of this article please see: http://arthritis-research.com/viewpoints/ar1031.asp\#ubersax

3. Zhong XP, Hainey EA, Olenchock BA, J ordan MS, Maltzman JS, Nichols KE, Shen H, Koretzky GA: Enhanced T cell responses due to diacylglycerol kinase zeta deficiency. Nat Immunol. 2003, 4: 882-90. For the Faculty of 1000 evaluation of this article please see: http://arthritisresearch.com/viewpoints/ar1031.asp\#zhong

4. Wald D, Qin J, Zhao Z, Qian Y, Naramura M, Tian L, Towne J, Sims JE, Stark GR, Li X: SIGIRR, a negative regulator of Toll-like receptor-interleukin 1 receptor signaling. Nat Immunol. 2003, 4: 920-7. For the Faculty of 1000 evaluation of this article please see: http://arthritisresearch.com/viewpoints/ar1031.asp\#wald

This PDF file was created after publication. 